\title{
MICROMORPHOLOGY OF THE EPIDERMIS OF THE FLORAL NECTARY OF RHODODENDRON JAPONICUM (A. GRAY) J. V. SURINGAR EX E.H. WILSON
}

\author{
Elżbieta Weryszko-Chmielewska, Mirosława Chwil
}

\author{
Department of Botany, Agricultural University of Lublin, 20950 Lublin, Akademicka 15, Poland \\ e mail: elzbieta.weryszko@.ar.lublin.pl
}

Received: 14.02.2007

\section{S u m m a r y}

The conducted study related to the structure of the floral nectaries of Rhododendron japonicum (A. Gray) J. V. Suringar ex E. H. Wilson. The structure of the secretory epidermis of the nectaries was analysed by using scanning electron microscopy (SEM). Rhododendron japonicum develops the superior pistil with a 5 loculed ovary equipped in five ribs. The nectary gland is located in the lower part of the ovary. In the nectary regions located on the extension of the ribs of the ovary, stomata were very numerous. In the upper part of the nectary, stomata were arranged individually or in small clusters, whereas at its half height they formed stomatal areas. The stomata were at different growth stages. They were arranged in different directions. The stomata developed on the nectary surface according to the mosaic pattern. The stomata from the lower situated part of the nectary had a different structure than those occurring in the upper half of the nectary. The stomata in the nectaries of $R h$. japonicum belong to the actinocytic type. The cuticle layer in the upper part of the nectary was better developed and had a characteristic sculpture, whereas in the lower part it was smooth.

Key words: nectary, morphology, epidermis, stomata, cuticle, Rhododendron japonicum

\section{INTRODUCTION}

Rhododendron japonicum (A. Gray) J. V. Suringar ex E. H. Wilson grows in natural habitats in Japan, where it is found in forest undergrowth. It was brought to Europe in the $19^{\text {th }}$ century. In Poland it is cultivated as an ornamental shrub with pink, orange and brick-red flowers (Seneta and Dolatowski, 2004). In breeding, $R$ h.japonicum is a valuable parent form due to its high frost resistance (Miyajima et al. 2000; Okamoto et al. 2006). Many hybrids and varieties are known, developed from multiple crosses, with different colours of flowers, from white to red (Seneta and Dolatowski, 2004).

In Poland the flowering period for Rh. japonicum is in April and May. Flowers of different species from the genus Rhododendron produce nectar and pollen abundantly, and they are visited by bees, bumblebees and other pollinating insects (Maurizio and Grafl, 1969; Sabatini et al. 1989; Szklanowska and Denisow, 1994; Sai-Chit et al. 2000; Weryszko-Chmielewska and Chwil, 2005).

The nectary glands in flowers from the genus Rhododendron occur at the basal part of the ovary, forming larger or smaller different-shaped convexities, corresponding to the ribs of the ovary (Philipson, 1985). Due to the degree of development of the nectariferous tissue and the shape of the gland, the abovementioned author distinguished in the investigated species from the genus Rhododendron three morphological types of floral nectaries, which are also of taxonomic significance. According to the classification of Fahn (1952), the nectaries of Rhododendron can be included in the group of style nectaries. Taking into account suggestions of Smets (1986), the floral nectaries found in the Rhododendron flowers belong to "nectaria persistentia" due to their location by the permanent parts of the flower, which include the pistil.

In literature, no data have been found relating to the structure of the Rhododendron japonicum nectary. This paper presents results of the study on the micromorphology of the nectary of this species conducted by using scanning electron microscopy. Special attention was paid to the distribution and structure of stomata. 


\section{MATERIAL AND METHODS}

The object of the study conducted in the years 2005-2006 was Japanese azalea (Rhododendron japonicum (A. Gray) J. V. Suringar ex E. H. Wilson). The investigated shrubs grew in the Botanical Garden of the Maria Curie-Skłodowska University in Lublin. Observations of the morphology and structure of the secretory epidermis of the floral nectaries of Japanese azalea were made by using scanning electron microscopy (SEM). Flowers were collected at the bursting bud stage. The sampled flower fragments (the ovary of the pistil with the nectariferous tissue) were fixed in $4 \%$ glutaraldehyde and $0.1 \mathrm{M}$ phosphate buffer with the $\mathrm{pH}$ of 7.0, at room temperature for 4 hours. After dehydrating in acetone, the plant material was dried at critical point in liquid $\mathrm{CO}_{2}$ and coated with gold by using the CS 100 Sputter Coater. Observations of the nectaries were made using the $\mathrm{BS}-340$ Tesla microscope.

\section{RESULTS}

The orange-red, five-petal corolla of the Rhododendron japonicum flower is protected from below by a calyx, composed of 5 sepals equipped on the edges in long, spiky outgrowths (Fig. 1). These outgrowths are multi-celled, and their length ( $3 \mathrm{~mm})$ exceeds the length of the sepals. In the flower, there are 5 stamens and the superior pistil with a 5-loculed ovary which is densely covered by different-sized non-glandular trichomes (Figs. 2, 3, 4). The ovary is equipped in five ribs, what is particularly well visible in cross section (Fig. 3). One of the ribs reaches larger dimensions.

The nectary gland is located at the base of the ovary, where it forms rounded convexities by the particular ribs (Figs. 2, 5, 6). The best-developed part corresponds to the position of the largest rib of the ovary. The surface of the nectary is distinguished by the absence of trichomes. Its location below the boundary of the non-glandular trichomes covering the ovary can be determined with a naked eye. The height of the ovary is $5-6 \mathrm{~mm}$, and the height of the nectary about $0.6-0.7 \mathrm{~mm}$.

The nectary surface is covered by the epidermis made up of small polygonal cells with convex outer walls (Figs. 7-10). In the nectary regions located on the extension of the ribs of the ovary, many stomata are found (Figs. 7, 8). In the upper part of the secretory epidermis, they are distributed individually or in small clusters, whereas at half-height of the nectary they form stomatal areas numbering from several up to several dozen stomata (Figs. 8, 11, 12, 15, 16).

The outer walls of the epidermis cells in the upper part of the nectary were covered with marked cuticular striae with different patterns: parallel and undulate (Figs. 11-14). The cuticular striae were not observed on the surface of the guard cells and the epidermal cells located in the lower part of the nectary (Fig. 15), in particular in the sectors corresponding to the hollows between the ribs (Figs. 9, 10). Many fewer stomata occurred in those places.

At the beginning of flowering (bud opening), the stomata were at various growth stages. In addition to open, fully-developed stomata (Figs. 11, 12, 13), precursors of guard cells and immature stomata, small-sized, closed, without the marked outer cuticular ledges, were observed (Figs. 11, 12, 14). The stomata developed on the nectary surface according to the mosaic pattern. In this model of development, mature stomata occur beside immature stomata. It was also noted that the stomata from the lower situated part of the nectary had a different structure than those occurring in the upper half of the nectary. The stomata situated in the lower part of the nectary had very poorly-developed outer cuticular ledges (Fig. 16), contrary to the stomata located in the upper part of the nectary below the trichomes covering the ovary (Figs. 12, 13). Most of the stomata were located at the level of other epidermal cells, and some of them, in particular in the upper part of the nectary, were raised above the surface of the epidermis. The cuticle of the outer wall of the guard cells was smooth.

In the case of the occurrence of large clusters of stomatal cells, it is difficult to speak about the occurrence and arrangement of subsidiary cells. However, stomata occurring individually can be classified to the actinocytic type with the subsidiary cells arranged radially (Fig. 13). The stomata were arranged in different directions on the surface of the nectary (Figs. 11, 12).

Due to the strong development of the outer cuticular ledges (wide ledges), the outer apertures of the pores were small. 

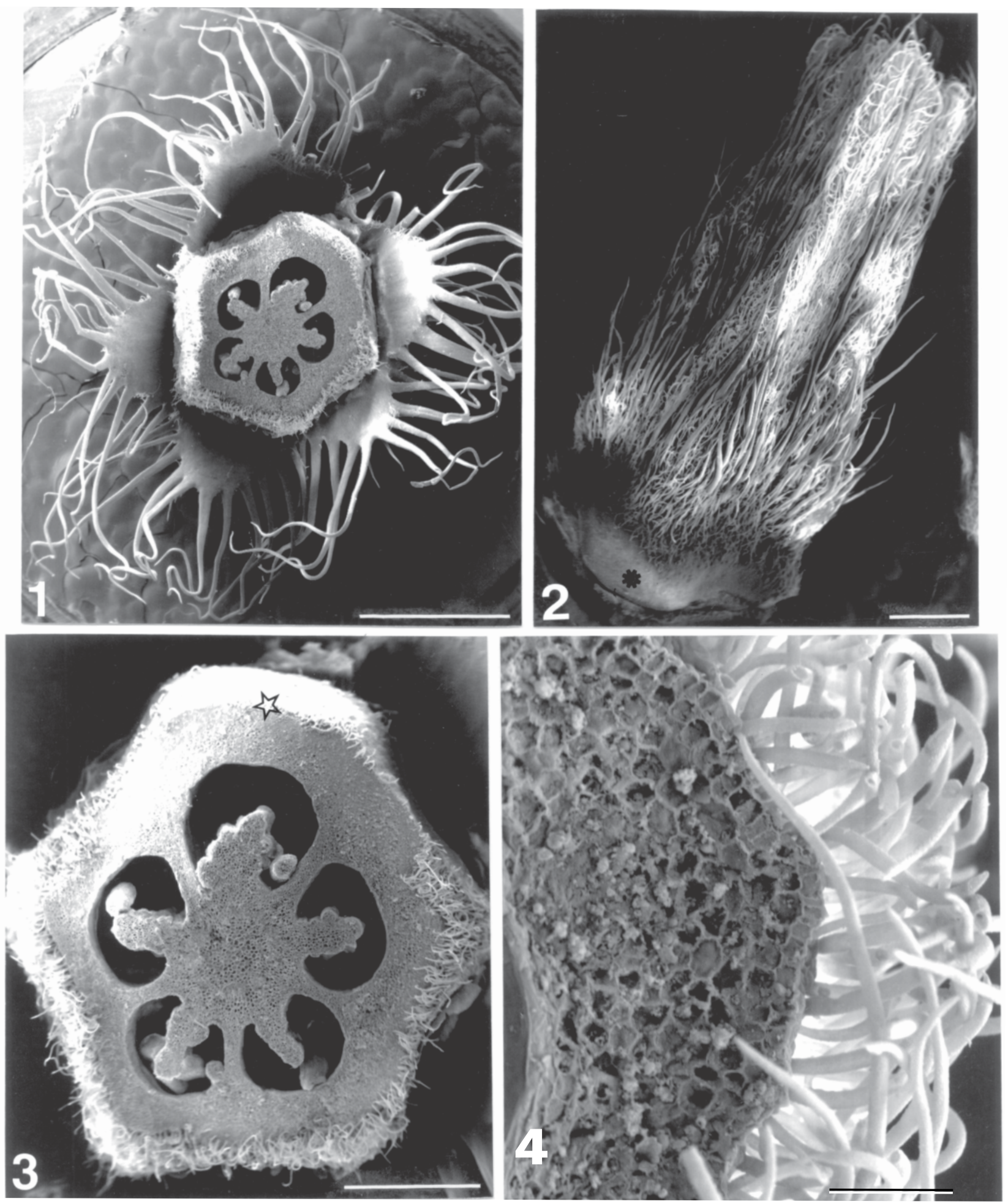

Fig. 1. Cross section of the ovary of Rhododendron japonicum. At the ovary base, visible are sepals with long outgrowths. Bar $2 \mathrm{~mm}$. Fig. 2. Ovary of Rh. japonicum, covered with non glandular trichomes, with the nectary visible at the base (asterisk). Bar $1 \mathrm{~mm}$. Fig. 3. Cross section of the five loculed ovary with one better developed rib (asterisk). Bar $800 \mu \mathrm{m}$.

Fig. 4. Fragment of cross section of the wall of the ovary with numerous unicellular trichomes. Bar $80 \mu \mathrm{m}$. 

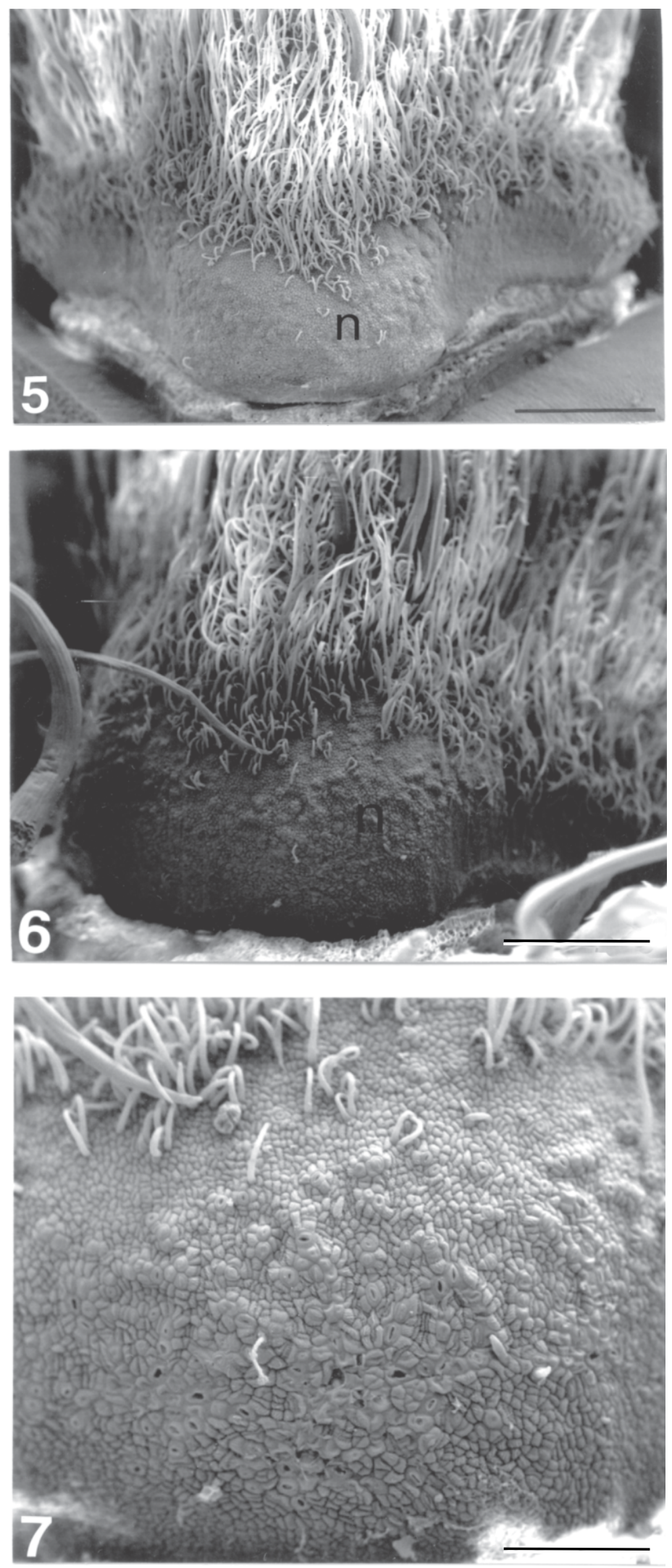

Figs. 5, 6. Nectary gland (N) of Rh. japonicum forming convexities in the lower part of the ribs of the ovary. Fig. 5 Bar $600 \mu \mathrm{m}$, Fig. 6 Bar $500 \mu \mathrm{m}$.

Fig. 7. Nectary surface with numerous stomata. Bar $200 \mu \mathrm{m}$. 

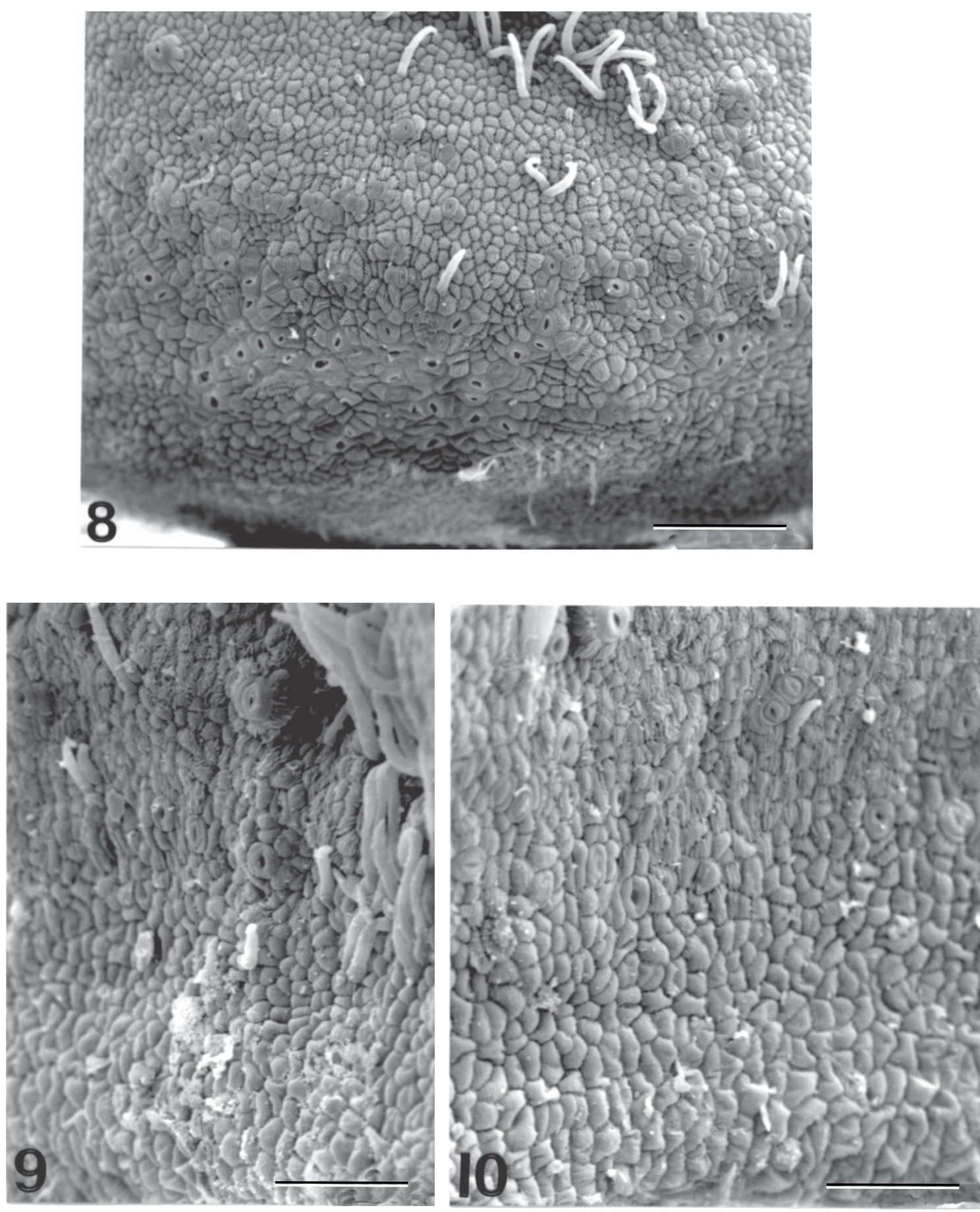

Fig. 8. Nectary surface from the rib region of the ovary. Numerous stomata visible. Bar $100 \mu \mathrm{m}$.

Figs. 9, 10. Fragments of the nectary surface in the region of the hollows between the ribs. Stomata are visible only in the upper part of the nectary. Fig. 9 Bar $90 \mu \mathrm{m}$, Fig. 10 Bar $80 \mu \mathrm{m}$. 

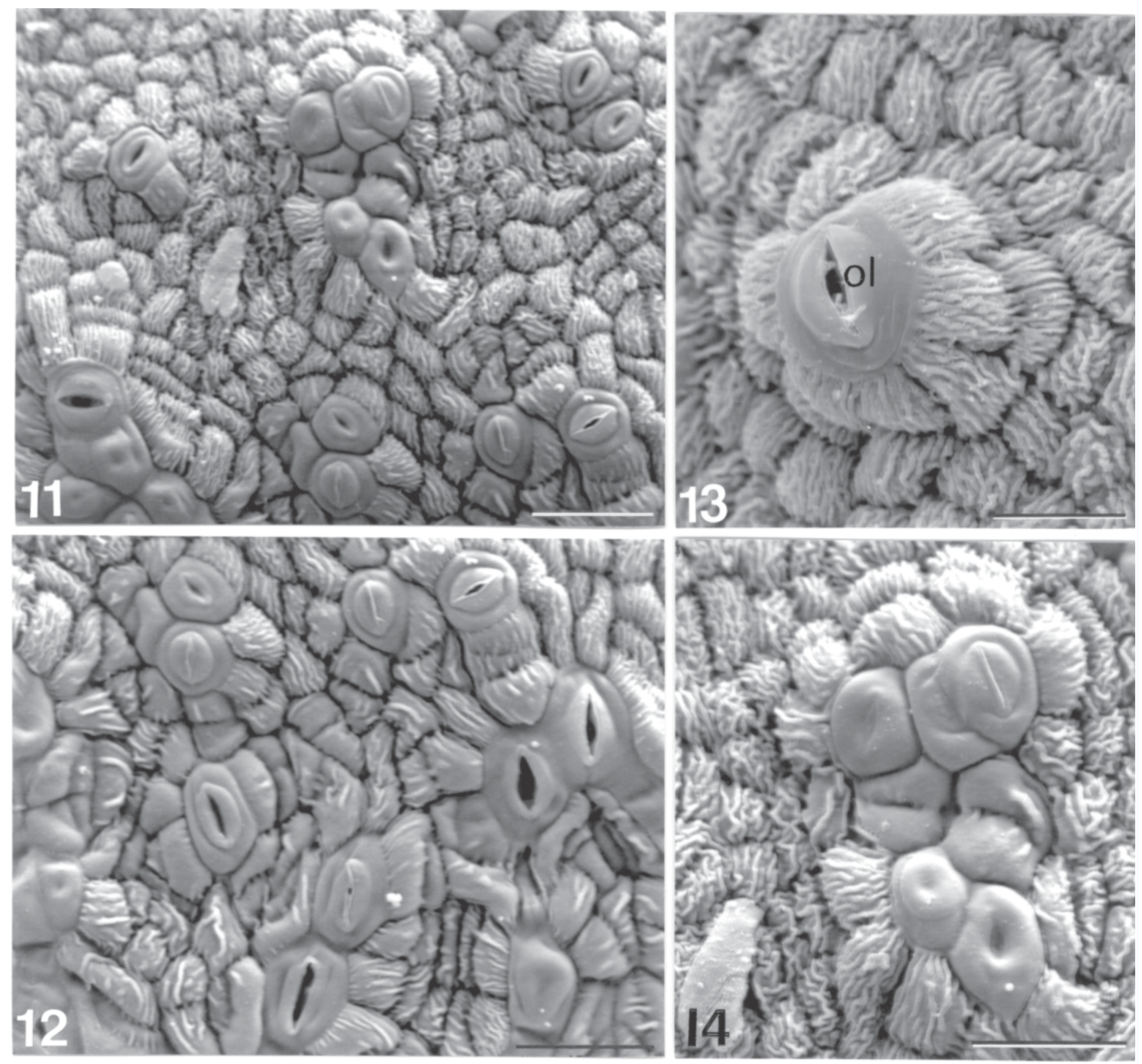

Figs. 11 14. Fragments of the epidermis from the upper part of the nectary, located in the rib region. Visible are stomata clusters and a single stoma (Fig. 13). On the surface of the epidermal cells, cuticular striae occur, whereas the cuticle covering the guard cells is smooth. Stomata are at different growth stages. In the mature stomata, well developed outer cuticular ledges (ol) are visible. Figs. 11, 12 Bars $40 \mu \mathrm{m}$, Fig. 13 Bar $20 \mu \mathrm{m}$, Fig. 14 Bar $30 \mu \mathrm{m}$. 

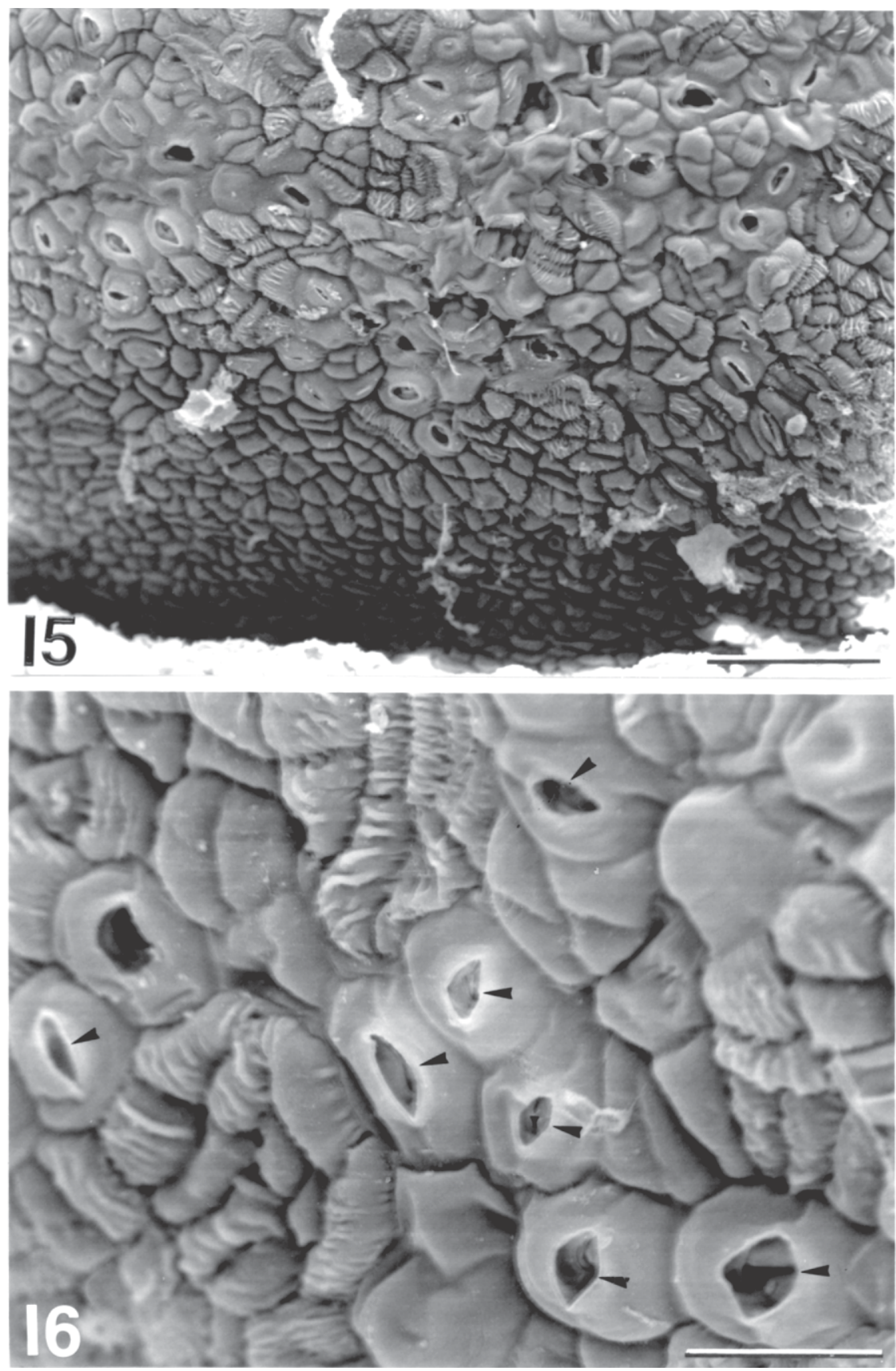

Figs. 15, 16. Fragments of the surface from the lower part of the nectary, located in the rib region. Visible are stomatal areas and more poorly developed cuticular striae on the epidermal cells. Guard cells have poorly developed outer cuticular ledges (arrowheads). Fig. 15 Bar $90 \mu \mathrm{m}$, Fig. 16 Bar $30 \mu \mathrm{m}$. 


\section{DISCUSSION}

The nectary in Rhododendron japonicum flowers forms a marked convexity in the lower part of each of the five ribs of the ovary. Philipson (1985) distinguished for species from the genus Rhododendron three types of nectaries, differing in shape. Taking into account this criterion, the nectary of $R h$.japonicum canbeclassifiedastypeA, characterised by a rounded convexity of the nectary gland, similarly to that distinguished in $R h$. jasminiflorum by Philipson (1985).

The occurrence of very numerous stomata, forming stomatal areas, in the epidermis of the floral nectaries of $R h$. japonicum, may prove the possibility of abundant nectar production in a short time. Tauber et al. (1980) and Davis and Gunning (1992) showed in other species that the amount of nectar produced by the flower depends on the number of stomata in the epidermis of the nectary.

The stomata in the epidermis of the $R h$. japonicum nectaries matured not synchronically, according to the mosaic pattern of stomata development, similarly to the model typical for leaves of dicotyledonous plants with reticulate venation, described by Esau (1973). The different rate of maturation of stomata in the nectaries of Eucalyptus is reported by Davis (1997), by Gaffal et al.(1998) inDigitalis, and by W is t and D a v is (2006) in Echinacea.

The outer walls of the guard cells of the $R h$. japonicum nectary were characterised by the presence of a smooth cuticular layer, contrary to the folded or striated cuticle occurring often on the surface of the guard cells in the nectaries of other plant species, e.g. Digitalis (Gaffal et al. 1998), Prunus (Radice and Galati, 2003), Echinacea (Wist and Davis, 2006).

Philipson (1985) found in the nectaries of different Rhododendron species the occurrence of modified, thus permanently open stomata. The stomata in $R h$. griersonianum presented by the abovementioned author differed significantly from the stomata of $R h$. japonicum investigated in our study: in terms of the size of the outer cuticular ledges, as well as in terms of the shape and size of the outer apertures.

In $R h$. japonicum, the well-developed outer cuticular ledges in the guard cells of the upper part of the nectary form a large outer vestibule in which nectar is initially stored. With the full opening of the central aperture of the pore, the outer cuticular ledges, restricting the size of the outer aperture, limit the width of the pore opening (Saxe 1979), what probably regulates the nectar flow rate.

The absence or very poor development of the outer ledges in the guard cells of the lower region of the nectary may result from smaller exposure of this portion to intensive evaporation or from the later development of this region of the nectary, or the adaptation to faster nectar release. S hön e r and B u k ov a c (1972) found that the degree of development of the outer and inner ledges in the guard cells of leaves affects the rate of water flow to the surface of these organs from the intercellular spaces.

The well-developed layer of striated cuticle on the outer walls of the epidermal cells in the upper part of the Rh. japonicum nectary can be assessed as a xeromorphic feature. The occurrence of only smooth cuticle in the lower part of the nectary, and in the middle part - the cuticle with few striae, can prove the basipetal development of the cuticular layer in the epidermis of the nectary of this species. Philips on (1985) showed in several other Rhododendron species a different degree of development and folding of the cuticle on the nectary surface. In $R h$. griersonianum, very well-developed striae occurred in the cuticle, similar to those observed by us in $R h$. japonicum. But in $R h$. campanulatum, the striae were small, and in $R h$. cinnabarinum the cuticle was smooth.

The cuticle performs the role of an important protective barrier on the epidermis surface. It limits transpiration, protects against excessive solar radiation, harmful environmental pollutants, feeding insects and the invasion of pathogens (Martin and Juniper, 1970; Juniper and Cox, 1973). It was found that the rich cuticular sculpture on the surface of corolla petals causes a stronger dispersion of sun rays (Juniper and J effree, 1983), and it may protect against the harmful effect of ultraviolet rays (Miros lavov, 1974).

\section{CONCLUSION}

1. The floral nectary of Rhododendron japonicum occurs at the base of the ovary, forming marked convexities by each of the five ribs of the ovary.

2. Nectar is secreted through very numerous stomata occurring individually or forming stomatal areas.

3. The portions of the nectary occupying the hollows between the ribs seem to be less active due to a smaller number of stomata.

4. The development of the nectary cuticle proceeds in the basipetal direction.

\section{REFERENCES}

Davis A. R., 1997. Influence of floral visitation on necta ry sugar composition and nectary surface changes in Eucalyptus. Apidologie, 28: 2742.

Davis A. R., Gunnig B. E. S., 1992. The modified stomata of the floral nectary of Vicia faba L. 1. Development, anatomy and ultrastructure. Protoplasma, 166: 134152.

Esau K., 1973. Anatomia roślin. PWRiL, Warszawa.

Fahn A., 1952. On the structure of floral nectarines. Bot. Gaz. 113: 464470 . 
Gaffal K. P., Heimler W., El Gammal S., 1998. The floral nectary of Digitalis purpurea L. Structure and nectary secretion. Ann. Bot. 81: 251262.

Juniper B. E., Cox G. C., 1973. The anatomy of the leaf surface: the first line of deference. Pestic. Sci. 4: 543 561 .

Juniper B. E., Jeffree C. E., 1983. Plant surfaces. Edward Arnold, London.

Martin J. T., Juniper B. E., 1970. The cuticles of plants. Edward Arnold, London.

Maurizio A., Grafl I., 1969. Das Trachtpflanzenbuch. Ehrenwirth Verlag, München.

Miroslavov E. A., 1974. Struktura i funktsiya epidermisa lista pokrytosemennych rastenij. Nauka, Leningrad.

Miyajima I., Ureshino K., Kobayashi N., Akabane M., 2000. Flower color and pigments of intersubgeneric hybrid between white flowered evergreen and yellow flowered decidous azaleas. Jour. Jap. Soc. Hort. Sci. 69(3): 280282.

Okamonto A., Ikeda H., Suto K., 2006. Variation in cros sability among Rhododendron japonicum f. flavum plants as pollen parents when crossed with evergreen species R. eriocarpum. Jour. Jap. Soc. Hort. Sci. 75(3): 270272.

Philips on M. N., 1985. The Rhododendron nectary. Notes RBG Edinb. 43(1): 117131.

Radice S., Galati B. G., 2003. Floral nectary ultrastrukture of Prunus persica (L.)

Batch cv. Forastero (Newcomer), an Argentine peach. Plant. Sys. Evol. 238: 2332.

Sabatini A. G., Persano Oddo L., Piazza M. G., Accorti M., Nanetti A., 1989. Glucide spectrum in the main Italian unifloral honeys. I. Fructose and glu cose. Apicoltura, 5: 3546

Sai Chit Ng., Corlett R.T., Ng S.C., 2000. Com parative reproductive biology of the six species of Rhododendron (Ericaceae) in Hong Kong, South China. Can. J. Bot. 78(2): 221229.

Saxe H., 1979. A structural and functional study of the coordi nated reactions of invidual Commelia communis L. sto mata (Commelinaceae). Amer. J. Bot. 66(9): 10441052.

Schöner J., Bukovac M. J., 1972. Penetration of stomata by Liqnids. Plant Physiol. 49: 813819.

Seneta W., Dolatowski J., 1997. Dendrologia. Wydaw. Nauk. PWN, Warszawa.

Smets E., 1986. Localization and systematic importance of the floral nectarines in the Magnoliatae (Dicotyledons). Bull. Jard. Bot. Nat. Belg. 56: 5176.
Szklanowska K., Denisow B., 1994. Blooming biology and some qualities of nectar and pollen of members of the genus Rhododendron L. Ann. Univ. Mariae Curie Skłodowska, sect. EEE, Hortic. 2: 203207.

Trauber L. R., Albertsen M. C., Barnes D. K., Heichel G. H., 1980. Structure of floral nectaries of alfalfa (Medicago sativa $\mathrm{L}$.) in relation to nectar produc tion. Am. J. Bot. 39: 433439.

Weryszko Chmielewska E., Chwil M., 2005. Morpho logical features of the nectary and of the pollen grains and the foraging value of the flowers of yellow azalea (Rhododendron luteum Sweet). J. Apicult. Sci. 49(2): 512.

Wist T. J., Davis A. R., 2006. Floral nectar production and nectary anatomy and ultrastructure of Echinacea purpurea (Asteraceae). Ann. Bot. 97: 177193.

\section{Mikromorfologia epidermy nektarnika kwiatowego Rhododendron japonicum \\ (A. Gray) J. V. Suringar ex E. H. Wilson}

\section{Streszczenie}

Przeprowadzone badania dotyczyły struktury nektarników kwiatowych Rhododendron japonicum (A. Gray) J. V. Suringar ex E. H. Wilson. Budowę epidermy sekrecyjnej nektarników analizowano w skaningowym mikroskopie elektronowym (SEM). Rhododendron japonicum wykształca górny słupek z 5-krotną zalążnią wyposażoną w pięć żeber. Gruczoł nektarnikowy położony jest $\mathrm{w}$ dolnej części zalążni. W regionach nektarnika położonych na przedłużeniu żeber zalążni szparki były bardzo liczne. W górnej części nektarnika szparki rozmieszczone były pojedynczo lub w małych skupieniach, zaś w połowie jego wysokości tworzyły pola szparkowe. Aparaty szparkowe znajdowały się w różnych fazach rozwoju. Były położone różnokierunkowo. Rozwój aparatów szparkowych na powierzchni nektarnika odbywał się według wzoru mozaikowatego. Aparaty z niżej położonej części nektarnika miały inną budowę, niż występujące w górnej połowie nektarnika. Szparki w nektarnikach Rh. japonicum należą do typu aktynocytycznego. Warstwa kutykuli w górnej części nektarnika była lepiej rozwinięta i miała charakterystyczną skulpturę, natomiast w dolnej części była gładka. 
